\title{
COOPERATIVE LEARNING ON EFL PROFICIENCY; THE BEST PRACTICE AT ISLAMIC HIGH SCHOOL STUDENTS
}

\begin{tabular}{|c|c|}
\hline & $\begin{array}{l}\text { Andriyono } \\
\text { English Teacher, MAN } 2 \text { Praya, Indonesia } \\
\text { responding Author Email: andriyono@gmail.com }\end{array}$ \\
\hline Article Info & Abstract \\
\hline $\begin{array}{l}\text { Article History } \\
\text { Received: June } 2020 \\
\text { Revised: June } 2020 \\
\text { Published: July } 2020\end{array}$ & $\begin{array}{l}\text { The study was aimed at finding out the effectiveness of cooperative language } \\
\text { learning on students' English proficiency as measured by their abilities in } \\
\text { grammar, reading comprehension, vocabulary, and listening comprehension. The } \\
\text { study also sought to measure students' attitudes towards cooperative learning }\end{array}$ \\
\hline $\begin{array}{l}\text { Keywords } \\
\text { Cooperative learning; } \\
\text { English proficiencies; } \\
\text { English language } \\
\text { teaching; }\end{array}$ & $\begin{array}{l}\text { and motivation to learn English. This study was a comparative research design in } \\
\text { the form of a non-equivalent control group design. The experiment lasted for } \\
\text { twelve weeks in which two intact groups from two Class of MAN } 2 \text { Praya were } \\
\text { chosen as the study groups. Subjects of this study consist of } 44 \text { students who } \\
\text { attended classes. The control group includes } 53 \text { students. This study tested the } \\
\text { effectiveness to examine the method; two quantitative tools for data collection } \\
\text { were used to compile the findings of the study. For starters, a pre-and post-test } \\
\text { were administered to measure English proficiency before and after the treatment. } \\
\text { Afterward, a questionnaire was set to measure students' attitudes towards } \\
\text { cooperative learning and motivation to study English in a new high school } \\
\text { system. After analyzing the data, the results indicated that cooperative learning } \\
\text { in the new system positively affect some aspects of the participants' English } \\
\text { proficiency and they had a positive attitude towards cooperative learning in the } \\
\text { new system and a higher motivation to learn English. }\end{array}$ \\
\hline
\end{tabular}

How to cite: Adriyono. (2020). Cooperative learning on EFL proficiency; The best practice at Islamic high school students. JOLLT Journal of Languages and Language Teaching. 8(3), 276-286, DOI: https://doi.org/10.33394/jollt.v\%vi\%i.2752

\section{INTRODUCTION}

English as a foreign language is taught in Indonesian schools and other learning institutions. It is a language used for international communication hence those who master and speak it well; reap many academic, social, and professional benefits (Efrizal, 2012). In a school setup, proficiency in English will make the learning of other subjects much easier. Bashir, Azeem, and Dogar (2011) have proposed ways of enhancing learners' speaking skills with the help of different methods of teaching, the use of appropriate exercises and a learnercentered approach to teaching and learning. By use of the teacher-centered approach to teaching and learning, teachers seem to do most of the talking and act as the only source of knowledge to students while students are treated as passive recipients in the learning process (Ning, 2011). These types of methods according to Gomleksiz (2007) have negatively affected students and produced incompetent users of the English language who are unable to improve their speaking skills. On the other hand, in the learner-centered approaches, students are given the opportunity to express themselves in speaking the language. English classes are mainly taught using teacher-centered methods (Murray \& Christison, 2010). The available communication and interaction in the classroom insufficient to enhance learners' speaking skills which should be developed along with other skills such as listening, reading, and writing (Haerazi, Vikasari, \& Prayati, 2019). This is because the integration of the skills will enhance the students' ability to communicate. 
The Education system plays an important role in society. The Indonesian government has decided to focus its education efforts on preparing students to enter the modern life of the twenty-first century. Therefore, the ninth development plan focused on improving the educational environment to meet the quantitative and qualitative needs of the next stage, developing advanced curricula to ensure comprehensive. Also, the development of students to enable them to contribute to building the community and enhancing the qualitative efficiency of educational staff to enable them to comprehend the objectives of modern educational curricula. (Report of the Ninth Developmental Plan, 2010).

According to several studies (e.g., Alhamed, 1999; Basamh, 2002; Merebah, 1987), the traditional state of the nature of classroom instruction in Indonesia depends heavily on lecturing and memorization. Most of MAN 2 Lombok Tengah teachers adopted the traditional didactic methods. The teacher delivers a lecture and students receive it. Students usually do not participate in exploring information; rather, they passively get information and they seldom express themselves. Students' participation is limited by teachers and textbook questions which usually are at the lower levels of Bloom's taxonomy (Ministry of Education, 2003).

Instruction in Indonesian schools is based on teacher presentation regardless of the subject matter. It is informed by Sianipar et al. (2020) that English teacher starts the lesson by presenting information, while the students listen. It is called teacher-centered learning (Marwan, 2017). Also, teachers also ask some questions to clarify unclear points. These questions are often directed to volunteer students. The last part of class time is given to independent work, and students engage in individual work and compete to get teacher rewards in verbal or pointing ways (Silalahi, 2020). During independent work, some teachers circulate to help students with their individual work. Because of the limit of class time and a large number of students the teacher does see not all students. Also, teachers do not come back to students who still do not understand the materials. Teachers do not allow students to cooperate to help each other because most teachers believe that demonstrating and teaching is the teacher's job. The Ministry of Education in Indonesia has worked hard to shift the curriculum and its teaching methods to the use of new teaching strategies, including discussion, discovery, scientific, cooperative learning, and so on.

Cooperative learning is a generic term for various small group interactive instructional procedures. Students work together on academic tasks in small groups to help themselves and their teammates learn together. It can be an effective method to motivate students, encourage active learning, and develop key critical-thinking, communication, and decision-making skills. David Jaques (2000) suggests that "Learning in groups, rather than informal lectures or training sessions, allows students to have greater scope to negotiate to mean and to express themselves within the language of the subject. It can also play a central part in developing key professional skills, such as listening, presenting ideas, persuasion, self-direction, selfmonitoring, and team working" ( Jaques, 2000 p.4).

Abrami (et al.) (1995), Jacobs \& Hall (2002), and Jacobs \& Small (2003) indicate that using cooperative learning improves cognitive processes in students because they elaborate and organize information in their minds, as they work together to comprehend a passage. Cooperative group members can use their own as well as their teammates' background knowledge to comprehend the task by relating an event or events in the passage to their own experience.

Cooperative learning is not a new strategy; it has existed for many years, and there is a huge body of research to support cooperative learning in the classroom. It operates with three principles: group goal, individual accountability, and equal opportunity for success. The teacher's role in implementing cooperative learning includes instruction and monitoring students, and active involvement in helping students to get the advantages of collaborative 
learning. As a result, through cooperative learning, we may be able to improve student achievement in MAN 2 Lombok Tengah.

The new high school project (developed high school) is a modern method in teaching and presenting materials to high school students. It has new subjects, curricula, and systems that facilitate learning and prepare students for the coming phase of their educational journey, which is the university. In this system, new subjects are introduced like business management, vocational education, life skills, and statistical mathematics. The project applies the hour's system for attendance. Students in the first year should attend 8 hours a day for 48 weeks. As they develop and go to another year these hours decrease. In MAN 2 Praya, the methods were applied in five times in Class A, and 6 times in Class B. This study, the Islamic secondary public high school or MAN 2 Praya was chosen to practice and implement the new way of teaching method which mainly depends on communicative classrooms, based on cooperative learning and group work.

\section{RESEARCH METHOD \\ Research Design}

This study is of a comparison design known as the non-equivalent control group design. In this design, the researcher presents one approach in the spectrum of scientific research methods and in some ways is a "hybrid of other methods", drawing on aspects of both experimental science and descriptive research. Similar to experimentation, comparison seeks to decipher the relationship between two or more variables by documenting observed differences and similarities between two or more subjects or groups (Carpi \& Egger 2008). In contrast to experimentation, the comparative researcher does not subject one of those groups to treatment, but rather observes a group that either by choice or circumstance has been subject to treatment. Moreover, comparative research is similar to experimentation in that it involves comparing treatment group to control, but it differs in that the treatment is observed rather than being consciously imposed due to ethical concerns, or because it is not possible.

Thus comparison involves observation in a more "natural" setting, not subject to experimental confines, and in this way evokes similarities with description. Comparison is used to determine and quantify relationships between two or more variables by observing different groups that either by choice or circumstance are exposed to different treatments. This kind of research design was significantly strengthened in the late 19th to the early 20th century with the invention and popularization of modern statistical methods (Carpi, Egger 2008). In this study, the researcher did not compose the cooperative learning experiment; it was already developed with no interference from him.

\section{Population and Sample}

The population of the study is the first year of high school students at MAN 2 Lombok Tengah. The schools represent the two teaching systems used in MAN 2 Lombok Tengah. The first school uses the "newly developed high school program" and the other one uses the traditional way of teaching. The subjects' age varies between $15 \& 16$ years old. The students in the first school were exposed to cooperative teaching methods from the first day and through all their classes. Group work is focused on and emphasized in all subjects.

\section{Instruments}

The researcher used two quantitative tools for data collection in this study: a pre and post-test and a 5 point Likert-type scale questionnaire. The pre and post-tests were given to both groups while the questionnaire was given only to the students in the developed highschool. The questionnaire aimed at measuring students' attitudes towards cooperative learning in English classrooms and their motivation towards using the target language in the new system. 


\section{Data Analysis}

To analyze the obtained data, the researcher used descriptive statistics to describe the basic features of the collected data. Descriptive statistics are necessary to show the distribution, the central tendency (mean, median, and mode), and the dispersion (standard deviation) of data. Inferential statistics such as the independent samples $t$-tests, the pairedsamples $t$-tests, and the Pearson product-moment correlation coefficient were used to compare the mean scores of both groups, to measure student progress in each group, and to compare student performance on one post-test with that of another.

\section{RESEARCH FINDINGS AND DISCUSSION Research Findings}

The first research question: Is cooperative learning effective when it comes to learning English as a foreign language for Islamic high school students in Praya? And the second question: Do students develop linguistic features while being involved in cooperative structures? To answer these two questions, one needs to compare the performance of students in both groups before and after the treatment. The pre-test was crucial in determining the initial equivalence between the cooperative learning group and the control (traditional) group.

Table 1

The score of t-test of English proficiency between the two groups

\begin{tabular}{lccccc}
\hline \multicolumn{1}{c}{ Group } & $\mathrm{N}$ & Mean & $\begin{array}{c}\text { Std. } \\
\text { Deviation }\end{array}$ & t-Value & $\begin{array}{c}\text { Sig. } \\
\text { (2-tailed) }\end{array}$ \\
\hline $\begin{array}{l}\text { Cooperative } \\
\text { learning group }\end{array}$ & 44 & 97.95 & 10.32 & 0.236 & 0.814 \\
\hline Control Group & 53 & 97.94 & 9.74 & & \\
\hline
\end{tabular}

To ensure the equality of both groups, the researcher used the independent-samples $t$ test. Results of the English proficiency pre-test (see Table 4-1) showed that there was no significant difference between the two groups. The mean score of the cooperative learning group $(\mathrm{n}=44)$ was $(97.95)$ with a standard deviation (SD) of $(10.32)$, whereas the control group $(\mathrm{n}=53)$ scored $(97.47)$ with an SD of (9.74). As shown in Table 1, the Sig. (2-tailed) was $\mathrm{t}(95)=0.236, \mathrm{P}=0.814$ and it is greater than $(0.05)$; hence one can conclude that there was no significant difference in the mean scores for each of the two groups before experimenting. The results do not reveal significant differences between the mean scores of the two groups before the starting of the study. To investigate the gains the cooperative learning group made in their English proficiency test after undergoing the treatment, a t-test was applied to the scores of the group's English proficiency pre and post-test.

Table 2

The score of t-test of the English proficiency pre and post-test of in the CLL group

\begin{tabular}{|c|c|c|c|c|c|c|c|c|}
\hline \multirow{3}{*}{ No } & \multirow{3}{*}{ Test } & \multirow{3}{*}{ Mean } & \multirow{3}{*}{$\mathrm{N}$} & \multirow{3}{*}{$\begin{array}{c}\text { Std. } \\
\text { Deviation }\end{array}$} & \multicolumn{2}{|c|}{ Paired Differences } & \multirow{3}{*}{ t-Value } & \multirow{3}{*}{$\begin{array}{c}\text { Sig. } \\
(2- \\
\text { tailed) }\end{array}$} \\
\hline & & & & & Mean & Std. & & \\
\hline & & & & & & Deviation & & \\
\hline 1 & Pre & 97.55 & 44 & 10.32 & 104.79 & 13.76 & 3.265 & 0.002 \\
\hline 2 & Post & 104.79 & 44 & 13.76 & & & & \\
\hline
\end{tabular}

The results indicated in Table 2 (4-2) showed that the cooperative learning group's pre-test mean score was (97.55) with SD of (10.32) while the post-test was (104.79) with SD 
of (13.76), and the t-value was (3.265). The variation between the two mean scores indicates that the cooperative learning group improved significantly after undergoing the treatment. The analysis, as shown in table (4-2), indicates a significant difference, favoring the post-test in the cooperative learning group. Both means of measurement revealed that the sig (2-tailed) is less than (.01), therefore, the difference in English proficiency between the two tests is statistically significant. To have more investigation of the gains the CLL group made in their English proficiency after undergoing the treatment, a t-test was applied to the scores of the two groups post-test.

Table 3

The score of t-test of the English proficiency post-test between the two groups

\begin{tabular}{lccccc}
\hline Group & $\mathrm{N}$ & Mean & Std. & t-Value & Sig. \\
\cline { 2 - 6 } & & & Deviation & & (2-tailed) \\
\hline $\begin{array}{l}\text { Cooperative } \\
\text { learning group }\end{array}$ & 44 & 104.79 & 13.76 & 1.795 & 0.076 \\
\hline Control Group & 53 & 99.66 & 14.24 & & \\
\hline
\end{tabular}

The analysis, as shown in Table 3 indicates a significant difference, favoring the cooperative learning group. Both means of measurement revealed that the sig (2-tailed) is less than (.01); therefore, the difference in English proficiency between the two groups is statistically significant. Based on this result, the English classes in the new English teaching method of Islamic high education used MAN 2 Lombok Tengah with the use of cooperative learning is effective when it comes to teaching and learning English. To have a more detailed look at each part of the exam can be seen in Table 4.

Table 4

illustrates the results

\begin{tabular}{|c|c|c|c|c|c|c|}
\hline \multirow[t]{2}{*}{ Exam part } & M & $\begin{array}{c}\text { Control } \\
\text { Group }\end{array}$ & $\mathrm{n}$ & M & $\begin{array}{c}\begin{array}{c}\text { Cooperative } \\
\text { learning } \\
\text { group }\end{array} \\
\text { SD }\end{array}$ & $\mathrm{n}$ \\
\hline & 5.62 & 2.31 & 53 & 7.47 & 2.92 & 44 \\
\hline English grammar II & 6.11 & 2.46 & 53 & 7.95 & 2.72 & 44 \\
\hline English vocabulary & 2.96 & 1.56 & 53 & 2.63 & 1.64 & 44 \\
\hline English Comprehension & 2.33 & 1.90 & 53 & 3.52 & 2.75 & 44 \\
\hline Listening & 81.62 & 8.45 & 53 & 83.20 & 10.10 & 44 \\
\hline
\end{tabular}

Table 4 shows that the result of student English Grammar, Vocabulary, and Listening examination varieties describe that (1) there is no significant difference in the English grammar I test scores between the post-test of the control group $(\mathrm{M}=5.62, \mathrm{SD}=2.31)$ and the post-test of the cooperative learning group $(\mathrm{M}=7.47, \mathrm{SD}=2.92)$; $\mathrm{t}$ - value $(95)=$ $1.608, \mathrm{P}=0.111$; (2) There is a significant difference in the results of English grammar II test between the post-test of the control group $(\mathrm{M}=6.11, \mathrm{SD}=2.46)$ and the post-test of the cooperative learning group $(\mathrm{M}=7.95, \mathrm{SD}=2.72) ; \mathrm{t}(95)=3.491, \mathrm{P}=0.001$ for the post test of the cooperative learning group; (3) There is no significant difference in the English vocabulary test scores between the post-test of the control group $(\mathrm{M}=2.96, \mathrm{SD}=1.56)$ and the post-test of the cooperative learning group $(\mathrm{M}=2.63, \mathrm{SD}=1.64)$; $\mathrm{t}(95)=0.997, \mathrm{P}=$ 0.321 ; (4) There is a significant difference in the results of the English reading 
comprehension test between the post-test of the control group $(\mathrm{M}=2.33, \mathrm{SD}=1.90)$ and the post-test of thecooperative learning group $(\mathrm{M}=3.52, \mathrm{SD}=2.57)$; $\mathrm{t}(95)=2.529, \mathrm{P}=0.013$. for the cooperative learning group; (5) There is no significant difference in the results of the Listening test between the post-test of the control group $(\mathrm{M}=81.62, \mathrm{SD}=12.45)$ and the post-test of the cooperative learning group $(\mathrm{M}=83.20, \mathrm{SD}=10.10) ; \mathrm{t}(95)=0.677, \mathrm{P}=0.500$.

The third and the fourth research questions ask: Does it motivate students and encourage them to develop their language skills? Do the students have a positive attitude toward the use of cooperative learning? To answer this question, the researcher used the five-point Likert questionnaire shown in (Appendix B) to gather data. The 20-item questionnaire was administered to the participants of the cooperative learning group at the end of the semester to explore their attitudes towards cooperative learning used in the new high school system. The questionnaire was divided into two subscales exploring the belief that cooperative learning in English classes was helpful to student learning, and the acceptance of the new high school developed system.

The range was calculated for the scale where the range $=5-1=4$. By dividing the range by the number of categories (5), the result would be $4 / 5=0.80$ which represented the length of each category of the five scales. Then the length of the category was added to the lowest grade of the scale which is the number (1). So the first category was $(1+.80=1.08)$ (Dörnyei, 2003, P 96). This process was applied to the rest of the categories. The questionnaire contains 20 items set to check subjects' level of motivation to learn English using cooperative learning in the new system of high school and their attitude towards this new system.

By doing so, it can be seen that $70 \%$ of the subjects agreed that they were motivated to use group work in English classrooms in the new high school developed system. The analysis of subjects' responses indicated that items 1, 5, 6, 7, 8, 9, 10,12,13, 16, 17, 18, and 20 all scored above (3.40) which means that the subjects were motivated. $30 \%$ of subjects' responses were undecided for the items mean scores were > (2.60) to (3.40). In addition, though the majority of the responses showed positive attitude the grand mean score as stated in the table above was (3.192) which when compared to the scale measures supports that the subjects were neutral toward the cooperative learning process in the newly developed high school system.

\section{Discussion}

The first finding in the study revealed that the experimental group outperformed the traditional group in their English grammar test. This difference in students' performance can be justified because the experimental group carried out cooperative work activities. This technique (i.e., CL) seems to have improved subjects' grammar level in the target language. These findings are supported by multiple studies. As Liao (2005) points out on her paper that cooperative learning was found to have large positive effects on motivation and strategy use, and medium-to-large positive effects on grammar achievement. Overall, the findings indicated a consistent pattern in favor of cooperative learning over whole-class instruction in teaching the Taiwanese learners English grammar. The results of the exploratory questions indicated that cooperative learning improved motivation and strategy use of learners across all subgroups, but more so with those performing at higher and lower levels. Grammar achievement of learners at higher and lower levels was affected positively. Additional analyses also indicated cooperative learning positively affected learning at higher cognitive levels.

Also, According to Olsen and Kagan (1985), cooperative learning provides English students, more opportunities for language development than traditional language classes do. They argued that, quantitatively, cooperative learning amplifies active use of language when 
L2 students try to comprehend or produce the language within their cooperative groups. Liang (2002), in a discussion on how cooperative learning could have positively affected the language competence of her experimental learners, emphasized three factors: the increase in student talk for academic and social purposes, the incentive structure of positive interdependence, and the supportive and communicative learning environment. Survey studies conducted by Ghaith $(2002,2003 \mathrm{~b})$ indicated that the cooperative learners felt more academic and personal support from their peers and teachers, more class cohesion and fairness of grading, and less school alienation. Another survey study (Ghaith, 2001) suggested a clear cooperative structure and lucid guidance as to the possible reasons for positive cooperative learning effects. The findings of the present study suggest that these factors may also have played a role in enhancing the experimental learners' grammar achievement. Other possible reasons can be explained in light of the following motivational theories, social cognitive theories, and cognitive elaboration theories.

First, according to Locke and Latham's (1990) goal-setting theory, human behaviors, which, of course, include learning behaviors, are regulated by goals. Factors influencing the level of learners' goal setting and goal commitment include whether group goals, encouragement, and feedback exist in the learning situation. Having group goals on top of personal goals leads to stronger goal commitment to personal goals than having merely personal goals; giving encouragement and performance feedback enhances the level of goalsetting. All these three factors group goals, encouragement, and performance feedback were essential parts of the experimental curriculum.

Like all other cooperative learning methods, the starting point of the experimental program was having group goals, which would motivate learners to offer both academic and psychological support, including encouragement and feedback, to each other. In the cooperative learning group, the feedback was rendered not only through peer assessment and correction but also through the routine calculation of individual improvement points and group average improvement points.

As for vocabulary acquisition, the results showed that both groups: cooperative learning and traditional, have no significant improvement in their post-tests. The post-measure of vocabulary acquisition between the two groups showed that the subjects of both groups have no statistically significant difference. Previous studies show that learning vocabulary is an ongoing process that takes time and practice. Nakata (2006) acknowledged that vocabulary acquisition requires continual repetition for effective vocabulary learning to take place (p. 19). Vocabulary acquisition is not something a student can spend time learning or memorizing, like grammar, and be successful. Maiguashca (1993) stated that teaching or studying grammar is based on a set of rules with a coherent structure that students follow or remember, but the same is not true of vocabulary (p. 91). The acquisition requires the learner to be disciplined, spending time each day working on words he/she does not know for learners to remember high-frequency words and put them into their long term memory, Nation and Waring (1997) stated that learners need to encounter the word multiple times in authentic speaking, reading, and writing context at the student's appropriate level.

$\mathrm{Gu}$ (2003) pointed out that vocabulary acquisition is a very learner-centered activity with the effectiveness of the learner's strategies depending on his/her attitude and motivation towards new vocabulary acquisition (p.2). That kind of learner center may not be highly focused on cooperative learning. Also, Shaaban (2006) investigated the effects of CLL on reading comprehension, vocabulary acquisition, and motivation to read. Subjects of that study were grade five EFL learners. The researcher reported that the results showed no significant difference between the control and the experimental group on the dependent variables of reading comprehension and vocabulary acquisition. Regarding the dependent variable of motivation to read, the results came quite significant in favor of the experimental group. 
That finding leads to the third finding of this study, this study showed that there is a significant difference in favor subjects in the cooperative learning group regarding reading comprehension. In recalling the findings of previous studies we can see that cooperative learning plays an important role in developing students' reading comprehension skills. Thornton (1999) used a method that combined traditional instruction with CLL in her reading class. She assigned her students to a group of eight and asked them to work together. The aim of CLL as Thornton mentioned was to allow all students to participate and to ensure comprehension. Regarding the effectiveness of CLL on reading, the researcher said, "Using a combination of traditional instructional methods and cooperative learning groups was an effective way to help students understand and analyze challenging texts" (P. 10).

Also, Chen (2005) did research in which she compared Cooperative Learning Approach to Grammar- Translation Method and examined whether CLL promotes motivation and how motivation affects listening, speaking, and reading performance. Chen stated in the research that there was no direct evidence between motivation and language skills improvement. Therefore, the researcher assumed that learners' high scores in listening, speaking, and reading are related to the "cooperative learning approach..., which fosters English language skills. In this study, students in the cooperative learning group used to have a reading passage out of 250-350 words once a week that they read and discussed together as a group. This kind of activity was not provided in the traditional group.

As for listening comprehension, the study shows that there is no significant difference in the results of the post-tests of both groups. That may be due to the lack of listening practice in both schools. The researcher noticed that there were no language labs in either school. Therefore, teachers used to skip listening exercises in text books. All in all, since cooperative language learning in the newly developed high school system affected some areas in English language proficiency positively, it is possible to say that the use of such a positive technique in English classrooms in MAN 2 Lombok Tengah would yield the same positive influence if not greater, which is proved in this study findings.

The analysis of the attitude questionnaire indicated that subjects of the cooperative learning group had a positive attitude towards cooperative learning in the new high school system. Students seem to agree that learning English in this new system with their group members helped them improve their English skills performance. Based on this, it is apparent that students do respond positively to cooperative learning in the Islamic high school Praya. In relation to previous studies, Alhaidar (2006) reported in his work that subjects who carried out reading tasks cooperatively showed a positive attitude towards this technique. Also, Atsuta (2003) carried out a study to improve unsuccessful learners' motivation where he incorporated cooperative learning as one of the many motivational strategies employed to achieve the intended goal. The findings of Atsuta showed the many advantages of CLL. These include making students more responsible for their learning, achieving a high level of motivation, and allowing students in a mix-ability environment to help one another and thus promoting the learning process.

Based on what is stated above, it is obvious that learners' responded positively to cooperative language learning in the new highly developed system in MAN 2 Lombok Tengah. In response to the fourth and fifth questions, the study revealed that subjects undergoing the treatment of cooperative learning in the new system were motivated to learn the target language. The implementation of cooperative learning in this new high school system seems to have motivated the participants to practice the English language. Results reported by Shaban (2006), Chen (2005), and Jacobs (2000) showed that cooperative language learning increased subjects' motivation to read in English. The same positive finding regarding the new high school system was stated by AlKatheri (2005); his study found that students have a positive attitude toward the new system and that they are motivated to learn 
under its umbrella. Also in 2009, a study done by Al-Shamek, Al-Fereh, and Abdulkareem showed positive application experience of the new secondary education system and courses. One can easily conclude that cooperative language learning in the new highly developed system leads to the same positive effect: motivation to use and learn the target language, and this was discovered in the findings of this study.

In summary, the results obtained from this study and the findings of other studies in relation to the topic all came in favor of cooperative language learning in the new highly developed high school system. It seems to have improved students' English performance. This approach to learning also appears to be generally accepted by learners. Additionally, this method has enhanced the subjects' motivation to use the target language. Thus, cooperative language learning in the new developed high school system has a positive impact on subjects' English performance and their attitude and motivation to learn it.

\section{CONCLUSION}

The general purpose of this study was to determine whether the use of cooperative language learning in the newly developed high school system will have a positive effect on students' English proficiency. The new high school system in MAN 2 Praya comes with many potential changes to the traditional way of teaching. One of them is using cooperative learning as a basic method in the classroom. The female high school students in MAN 2 Lombok Tengah in two different schools were the subject of this study. The study aimed to find if cooperative language learning in the newly developed high school system would enhance their English proficiency as measured by their abilities in grammar, reading comprehension, vocabulary, and listening comprehension. The study also sought to measure students' attitudes towards cooperative learning and motivation to learn English in the new high school system.

The results obtained from the pre-test measures showed that the two groups were equivalent prior to the treatment. However, post-test measures revealed a statistically significant difference between the two groups' performance in their grammar and reading comprehension in favor of the cooperative learning group. Additionally based on these findings, it was clear that cooperative learning did have a positive effect on the subjects who had undergone the treatment. As for the third and fourth questions, a questionnaire about motivation to learn and use English in the new high school system and their attitude toward that was given to subjects of the cooperative learning group after undergoing the treatment. Results based on the frequency distribution of subjects' responses showed that $57 \%$ of the experimental group students agreed that they became motivated to learn English using cooperative learning methods. ooperative learning did motivate subjects involved in the treatment to learn and practice English.

Findings further showed that 58\% of the experimental group students had a positive attitude towards the usage of cooperative learning in the new high school system. Students accepted cooperative language learning as a means of learning and improving English proficiency. Moreover, the findings of the present study show that, while cooperative learning enhances learning motivation and it promotes higher grammar achievement.

\section{ACKNOWLEDGEMENT}

The researcher realizes that this study cannot complete without any helps from others. Thus, the researcher wishes to express the special gratitude to those who contribute in any part of this manuscript. All of the lecturers and official teams are delivered many thanks for accomplishing this study. Thanks for giving the service and time during this study. In addition, I also thank the Headmaster and English teacher of MAN 2 Praya for permitting practice and apply this model. 


\section{REFERENCES}

Abrami, P. C., Chambers, B., Poulsen, C., De Simone, C., d'Apollonia, S., \& Howden, J. (1995). Classroom connections: Understanding and using cooperative learning. Toronto: Harcourt Brace.

Adams, Dennis M \& Hamm, Mary (1996). Cooperative learning : critical thinking andcollaboration across the curriculum (2nd ed). C.C. Thomas, Springfield, Ill., U.S.A

Akcan, S. (2000). Cooperative Learning Course Syllabus for Pre-Service Teachers. Paperpresented at the Annual meetings of Teachers of English to Speakers of Other Languages (Vancouver, BC, Canada, March 14-18, 2000). (EDRS Reproductions EDNo. 443296).

Alhaidari, M. (2006). The Effectiveness of Cooperative Learning to Promote Reading Comprehension, Vocabulary, and Fluency Achievement Scores of Male Fourth- and Fifth- Grade Students in MAN 2 Lombok TengahIn School. (ProQuest Information and Learning Company UMI No. 3229376).

Alhamed, M. (1999). Curriculum development between static and converted. Ministry of Education, MAN 2 Lombok TengahI, 35, 102-105

Atsuts, H. (2003). Improving the Motivation of Unsuccessful Learners in the Japanese HighSchool EFL Context. (EDRS Reproductions No. ED476750).

Barron, B, \& Hammon, L.(2012). Powerful Learning: Studies Show Deep UnderstandingDerives from Collaborative Methods Cooperative learning and inquirybased teaching yield big dividends in the classroom. And now we have the research to prove it. As retrieved fromhttp://www.edutopia.org/inquiry-project-learningresearch?page $=1$

Chen, M. (2005). The Effects of the Cooperative Learning Approach on Taiwanese ESLStudents' Motivation, English Listening, Reading, and Speaking Competencies. (UMINo. ED3168533).

Cheyne, J.A., \& Tarulli, D. (2005). Dialogue, difference, and voice in the zone of proximaldevelopment. In H. Daniels (Ed.), An introduction to Vygotsky (pp. 125-147). London: Routledge.

Chiu, A. (Ed.) (2000). Longman dictionary of contemporary English (5th ed.). Hong Kong: Longman.

Corbetta, P. (2003). Social research, theory, methods and techniques. London: Sage.

Dawes, J. (2008). Do data characteristics change according to the number of scale points used? An experiment using 5-point, 7-point and 10-point scales. International Journalof Market Research, 50(1), 61-77.

Dörnyei, Z. (2003). Questionnaires in Second Language Research: Construction, Administration, and processing. NJ: Lawrence Erlbaum associates.

Farmer, L. (1999). Cooperative Learning Activities in the Library Media Center. USA: Libraries Unlimited, Inc.

Ghaith, G. M. (2004). Correlates of the implementation of the STAD cooperative learning method in the English as a foreign language classroom. International Journal ofBilingual Education and Bilingualism, 7, 279-294.

Greenfield, R. (2001). A Collaborative E-mail Exchange for Teaching English as a Secondlanguage to Intermediate-Level ESL Students: A case study in a Hong Kong 
Secondary School. Ph.D. Dissertation, University of Leicester. (EDRS ReproductionsNo. ED459604).

Haerazi, H., May Vikasari, R., \& Prayati, Z. (2019). The use of scientific-based approach in ELT class to improve students' achievement and classroom interaction. Register Journal, 12(2), 157-180. https://doi.org/10.18326/rgt.v12i2.157-180

Haerazi, H., Prayati, Z., \& Vikasari, R. M. (2019). Practicing contextual teaching and learning (CTL) approach to improve students' reading comprehension in relation to motivation. English Review: Journal of English Education, 8(1), 139-146. https://doi.org/10.25134/erjee.v8i1.2011

Jacobs, G. M., \& Hall, S. (2002). Implementing cooperative learning. In J. C. Richards \& W. A. Renandya (Eds.), Methodology in language teaching: An anthology of currentpractice (pp. 52-58). New York: Cambridge University Press.

Jacobs, G., \& Ward, C. (2000). Analysing Student-Student Interaction from CooperativeLearning and Systematic Functional Perspectives. Earlier version presented at theinternational Systemic Functional Institute and congress. (EDRS Reproductions No. ED444356).

Kagan, S. (1985). Co-op: A flexible cooperative learning technique. In R. E.Slavin, S. Sharan, S. Kagan, R. Hertz-Lazarowitz, C. Webb, \& R. Schmuck (Eds.), Learning to cooperate, cooperating to learn (pp. 437-452). New York: Plenum Press.

Lee, S. (1999). Implementing Cooperative Learning at a Language School. Cooperative Learning. JALT Applied Materials. (EDRS Reproductions No. ED437844).

Liao, H.-C., \& Hsueh, Y.-U. (2005). Collaborative groups in Taiwan's ESL writing classes. Paper presented at the 39th Annual Teaching English to Speakers of Other Languages Convention and Exhibit (TESOL 2005) Graduate StudentForum, San Antonio, TX.

Marwan, A. (2017). Implementing Learner-Centered Teaching in an English as a Foreign Language (EFL) Classroom. Celt: A Journal of Culture, English Language Teaching \& Literature, 6-12. https://doi.org/https://doi.org/10.24167/celt.v17i1

Meteetham, P. (2001). Case study of cooperative learning by using jigsaw technique withsecond-year English major students at Naresuan University. M.A. Dissertation,Mahidol University.

Nakata, T. (2006). Implementing optimal spaced learning for English vocabulary learning: Towards improvement of the low-first method derived from the reactivation theory. The JALT CALL Journal, 2(2), 3-18.

Nation, P., \& Waring, R. (1997). Vocabulary size, text coverage and word lists. In N. Schmitt\&M. McCarthy (Eds.), Vocabulary: Description, acquisition and pedagogy (pp. 6-19). Cambridge, UK: Cambridge University Press.

Polly, E. (2007) Learner perceptions of small group and pair work in the ESL classroom:implications for conditions in second language acquisition. [M.A. theses].Proquestdissertations and theses. The University of Texas.

Sellers, J. A. (2005). Using cooperative learning in a content-based Spanish course: TheLatin American telenovela (Doctoral dissertation, University of Wyoming, 2005).Dissertation Abstracts International, 66 (03), 864A.

Sianipar, R., Sianturi, D., Situmorang, S., Gulo, P., \& Saragih, E. (2020). An analysis of recount text in English textbooks used by tenth grade students. Journal of Languages and Language Teaching, 8(2), 120-127. doi: https://doi.org/10.33394/jollt.v8i2.2280

Silalahi, D. (2020). English lesson plan implementation by teachers candidate in micro teaching course at FKIP of HKBP Nommensen University. Journal of Languages and Language Teaching, 8(2), 193-201. doi:https://doi.org/10.33394/jollt.v8i2.2542 